\title{
BOOKS
}

\section{Brutal Realities of British Rule in India}

\author{
SUMIT GANGULY
}

$\mathrm{I}$ $\mathrm{t}$ is curious that British historians were and for the most part remain the principal authors of scholarship on the British Empire in India. While a substantial amount of work by Indian historians has focused on the sources and features of the Indian nationalist and anticolonial movement against the British, few of them have taken on the colonial enterprise itself. Certainly, none of them has provided an overarching account of the origins and evolution of British rule in India. This remains an odd lacuna in the existing literature, especially considering the notable weaknesses and blind spots that long marred British histories of India.

An early generation of British historians, most notably Vincent Arthur Smith, who was prominent in the 1920s, treated the colonial enterprise as a largely anodyne affair. Furthermore, the scholarship of that era took a mostly chronological approach and focused disproportionately on the personalities and policies of particular British regimes in the subcontinent while ignoring the views of Indians themselves.

A subsequent generation of scholars, an exemplar of which was the noted British civil servant Sir Penderel Moon, did little to improve on the first wave. The same bias, with its suggestion that the vast majority of Indians simply accepted the inevitability of British rule (having previously accommodated themselves to other invaders), pervaded his account. Moon, like his predecessors, failed to recognize the obvious. A host of invasions had indeed characterized India's past; the key distinction between these and the British was that the earlier invaders adopted India as their homeland and became part and parcel of the political landscape.

SUMIT GANGULY is a professor of political science and of Indian cultures and civilizations at Indiana University, Bloomington, a senior fellow at the Foreign Policy Research Institute, and a Current History contributing editor.
Even as Moon was completing his magnum opus on the British colonial experience, which was published posthumously in 1989, a number of able British historians based at the University of Cambridge embarked on a close and careful examination of various aspects of British colonial rule in India. Among a host of other subjects, they traced the role of information and intelligence in the sustenance of the empire. One of the doyens of this field was the late Sir Christopher Bayly.

Subsequently, in 2000, Lawrence James, another British historian, published an important, thematic, and accessible account of British rule in India. James's account, unlike those of earlier generations of historians, acknowledged the many ills of colonial rule. Nevertheless, it emphasized the putative benefits that colonial administration had conferred on India, including the development of public services and infrastructure.

\section{COLONIAL CRIMES}

Jon Wilson's The Chaos of Empire is the work of a British historian who was trained at the University of Oxford and now teaches at King's College London. This book constitutes an important break from much previous scholarship for four compelling reasons.

First, it is a work of considerable sweep and imagination. It provides a rich, detailed, and indeed sometimes dizzying account of the activities and rivalries of the British and other colonial powers, most notably the French and the Portuguese, as they attempted to establish footholds in India. The level of specificity that he brings to bear is nothing short of granular, yet he also makes use of the occasional telling anecdote and lends a degree of freshness to tales that have long been told. Even readers knowledgeable about Indian history will find here a fascinating trove of mostly unknown accounts of particular features of British colonial rule. Probably few knew that 
India's first modern brewery was started in the military town of Kassauli in the Himalayan foothills as early as 1855 .

Second, unlike much prior scholarship, The Chaos of Empire makes little or no attempt to sanitize the British colonial enterprise. Instead it forthrightly addresses the chicanery, the racism, and the cupidity that characterized British rule. Wilson's discussion of one of the most brutal episodes of twentieth-century British colonial history in India, General Reginald Dyer's 1919 massacre of peaceful, unarmed protesters in the city of Amritsar in the Punjab, is unsparing. Similarly, in Wilson's account, the famines that took place under British rule are not attributed to mere vagaries of the climate. Instead, he bluntly discusses the role of colonial policies that adversely affected local agriculture. As he states:

Famine occurred when there was not enough work for people to feed themselves when climate conditions turned bad. The breakdown happened as India's workforce was exposed to greater competition from overseas, and India's rulers were unable or unwilling to support alternative ways for people to earn money or buy food.

Third, in a related vein, Wilson demonstrates how British rule actually impoverished India. He argues that it was not that Britain simply drained India of its resources. (It is important to mention, however, that the noted British economist Angus Maddison has marshaled an impressive array of statistical data to show that the costs of British administration certainly stultified economic growth in colonial India.) Instead, he argues that the economic institutions set up by the British focused on the pursuit of a very small range of industrial activities, mostly oriented toward processing primary products for export-tea, jute, and other textiles. These firms had evinced scant interest in employing substantial numbers of Indian workers or producing goods for the internal market.

Worse still, Wilson shows how famine relief efforts fell far short of what was needed to stave off mass starvation. While historians like Paul Greenough have thoroughly documented the horrors of the Bengal famine of 1942, not many have dis-

Current History presents its latest e-book:

\section{Public Spheres: A Current History Anthology}

What is the state of the public sphere around the world today? In an era of digital communications, information overload, and pervasive state surveillance and cybercensorship, is holding the government to account by means of rational debate still feasible? Can the public sphere still play such a role in the twenty-first century? Current History sought some answers to these questions by commissioning a series of essays on the public sphere in each of the different regions covered by our monthly issues. The pieces collected here originally appeared in the journal from September 2015 to May 2016.

ESSAYS INCLUDE:

Sebastian Veg on China

Alexander Etkind on Russia

Marc Lynch on the Middle East

Philip Oxhorn on Latin America

Jan-Werner Müller on Europe

Arvind Rajagopal on India

Ebenezer Obadare on Africa

For more information, contact: editors@currenthistory.com 
cussed the ravages of another famine in the late nineteenth century in the district of Bellary in south India, which killed 5.5 million. The British responded by setting up work camps that provided limited relief.

Finally, Wilson has spared readers a mere epochby-epoch account of the evolution of British colonial rule with a tiresome enumeration of the role of various personalities and their policies. While he does provide a chronological history, he emphasizes the choices of local actors, whether they opposed or collaborated with the British. More to the point, he places developments within British India in the larger sweep of the world-historical arc. To that end he emphasizes global developments that helped shape the British Empire in India as well as the empire's contributions to the external world.

It is hard to take issue with a book of this scope and complexity. Written in lucid prose, with clear arguments replete with copious evidence, it is indeed a tour de force. There are, however, two issues of some significance that might be raised.

Wilson devotes too much of his book to documenting and analyzing the forces that enabled the British to deftly defeat their principal rivals as they expanded their commercial (and later political) empire on the subcontinent. Perhaps as a result he was forced to trim his discussion of the emergence, growth, and evolution of Indian anticolonial nationalism. He does, in fairness, provide glimpses of these issues and discusses them with insight. However, more evidence and analysis on this front would have further strengthened his study.

Finally, given the existence of a vast corpus of scholarship on the significance of the partition of the subcontinent, it is odd that he spends a scant few pages on an event that cost the lives of at least one million people and led to the displacement of around twelve million. The brief description and analysis he provides is nonetheless quite insightful. For example, students of Partition will be intrigued to learn that Lord Mountbatten, the last viceroy, had made clear to British military authorities that no operational efforts were to be undertaken to maintain public order unless British lives were at stake. Given that Wilson obviously knows the colonial administration failed to make suitable arrangements for the transfer of power to the two successor states of India and Pakistan, it is a pity that he chose not to elaborate on this subject. Nor, for that matter, is there any discussion in his book of the sheer significance of Partition for the future course of Indo-Pakistani relations.

These objections aside, The Chaos of Empire is without question a landmark work of scholarship. It marks a clear and unequivocal departure from colonially inspired accounts that frequently airbrushed out of the picture the many loathsome features of the imperial venture in India. 